\title{
Islamic Leadership, Islamic Work Culture, and Employee Performance: The Mediating Role of Work Motivation and Job Satisfaction*
}

\author{
Sih Darmi ASTUTI ${ }^{1}$, Ali SHODIKIN² ${ }^{2}$ Maaz UD-DIN ${ }^{3}$
}

Received: August 01, 2020 Revised: October 05, 2020 Accepted: October 15, 2020

\begin{abstract}
This study aims to examine the influence of Islamic leadership and Islamic work culture on employee performance through work motivation and job satisfaction. This study was conducted at Universitas Islam Negeri (UIN) Walisongo Semarang, Indonesia, because so far, there is still very limited research on the relationships between Islamic leadership, work culture, and work motivation in educational personnel performance. The educational personnel performance is expected to increase at UIN Walisongo Semarang with continuous efforts to improve to survive and develop as much as possible. The population of this study was all educational personnel at UIN Walisongo Semarang, Indonesia. Of 186 people, only 127 people were involved in this study. The research method used was a survey method using primary data collected through questionnaires. This study's analysis technique employed multiple linear regression. The results uncovered that, out of the eight hypotheses proposed, six hypotheses were accepted. Islamic leadership and Islamic work culture were found to have no direct effect on employee performance. Besides, work motivation and job satisfaction became essential factors mediating Islamic leadership and Islamic work culture on employee performance. Spiritual values in leadership inspire employees to build the organization's vision and create job satisfaction, which in turn impacted employees' performance.
\end{abstract}

Keywords: Islamic Leadership, Islamic Work Culture, Motivation, Job Satisfaction, Employee Performance

JEL Classification Code: I23, M10, M12, O15

\section{Introduction}

Universitas Islam Negeri Walisongo is a university under the Ministry of Religion's authority by Regulation of the Minister of Religion No. 16 of 2016 concerning the Organization and Work Procedures of the Ministry

\footnotetext{
*Acknowledgments:

It is an independent study. The authors thank enumerators, who helped to collect the data.

${ }^{1}$ First Author and Corresponding Author. Business and Economics Faculty, Universitas Dian Nuswantoro, Indonesia [Postal Address: JI. Nakula I No. 11-15, Semarang, 50131, Indonesia]

Email: astutissda@dsn.dinus.ac.id

${ }^{2}$ Business and Economics Faculty, UIN Walisongo, Semarang, Indonesia

${ }^{3}$ Department of Management Sciences, University of Swabi, Pakistan

(c) Copyright: The Author(s)

This is an Open Access article distributed under the terms of the Creative Commons Attribution Non-Commercial License (https://creativecommons.org/licenses/by-nc/4.0/) which permits unrestricted non-commercial use, distribution, and reproduction in any medium, provided the original work is properly cited.
}

of Religion of the Republic of Indonesia. It is under the Ministry of Religion of the Republic of Indonesia that carries out governmental tasks in the field of education (Ministry of Religion of the Republic of Indonesia, 2016). To carry out its university's duties and functions, the Ministry of Religion issued the Regulation of the Minister of Religion No. 54 of 2015 concerning the Organization and Work Procedure of Universitas Islam Negeri Walisongo Semarang (Ministry of Religion of the Republic of Indonesia, 2016).

Furthermore, to fulfill the education task, the existing education system/service must refer to the Decree of the Minister of State Officer Number 63/KEP/M. PAN7/2003, regarding the General Guidelines for Public Service Administration. It states that public services are all service activities carried out by public service providers to meet the service recipients' needs and implement the law provisions. The Ministry of Religion has elaborated it in the Regulation of the Ministry of Religion No. 168 of 2010 concerning Guidelines for the Preparation of Operational Service Standards within the Ministry of Religion of the Republic of Indonesia (Ministry of Religion, 2010). 
The guidelines for preparing operational procedures within the Ministry of Religion encourage more effective, efficient, and accountable government administration. The government has launched the application of good and clean governance principles by implementing bureaucratic reform, which is generally aimed at improving services to the public. Operationally, the manifestation of improving the services' quality to the public is in the form of improving and perfecting the process of administering government administration so that it better reflects the bureaucracy that can carry out quality, satisfying, transparent, and accountable public service functions.

The commitment to advance and develop UIN Walisongo Semarang has been built since the educational personnel has been working and continuing to increase along with various jobs. It shows that the average educational workforce has a high appreciation of the Islamic work culture because, in the Islamic work culture, some attitudes and views refer to improving the HR (Human Resources) quality. The reality is that, basically, UIN Walisongo Semarang, in providing optimal services to the community, is facing fundamental obstacles, such as leadership, work culture, educational personnel performance, and leadership motivation.

In increasing the educational personnel motivation, a leader who can mobilize educational personnel well is required to be based on Islamic Sharia. This reason was the background for taking up the research topic on the impact of leadership on educational personnel performance. The embedded work culture rooted in UIN Walisongo Semarang made the educational personnel's work motivation higher. Some educational personnel were encouraged to perform congregational worship in the mosque, so others were motivated to do the same. As an institution with thick Islamic nuances, UIN Walisongo Semarang had various forms of activities. These activities included 1) study of Kitab Kuning every Monday and Thursday, 2) recitation on the Islamic holidays' celebration, and 3) Istighosah every time entering a new school year. Moreover, work motivation is essential to improve human resources' quality in institutions. Especially in UIN Walisongo Semarang, it relied heavily on human resources as the axis to carry out its activities. Therefore, human resources in institutions must have work motivation to produce satisfactory performance. The motivation includes 1) the provision of higher performance allowances for the educational personnel with good performance, and 2) work penalties (severe, mild, and moderate). At UIN Walisongo Semarang, the educational personnel performance referred to achievements as measured by the institution's standards or criteria. Each educational personnel was motivated to produce work for one year, and then the results or work achievements were given the benefit that has been determined by the institution.

The researchers investigated UIN Walisongo Semarang because, so far, there is still very limited research on Islamic leadership, work culture, and work motivation in educational personnel performance. The educational personnel performance is expected to increase at UIN Walisongo Semarang with continuous efforts to improve to survive and also be able to develop as much as possible. Based on these interests, the authors took this theme.

\section{Literature Review}

\subsection{Islamic Leadership}

Many definitions describe leadership, but it is fundamentally and commonly known as "Leadership," which means influencing people. Most people consider the leader a source of influence since a leader influences followers or as the party affected (Riva'i, 1974: 64). The leadership terms in the Qur'an are: First, the Caliph is a leader who bears the mandate and responsibility to carry out government and uphold the truth (Mohamad et al., 2012; Qur'an Surah Shaad, 38:26). Secondly, Imam is a leader who carries out tasks based on the guidance of Allah (Mohamad et al., 2012; Qur'an Surah Al Anbiya: 73). Third, Malik is a leader who fights and struggles to uphold the religion of Allah (Mohamad et al., 2012; Qur'an Surah Al Baqarah: 246). Fourth, the term Tankin is used by the Qur'an to show that power and influence had been given to leaders such as Zulkarnain, Prophet Joseph in Egypt, Prophet Muhammad SAW, clerics, and so on. The power was given to preach Allah's teachings (Mohamad et al., 2012).

Some leadership definitions in Islam's view mean that Islamic leadership is leadership according to Islamic ways and achieve a goal under the permission and pleasure of Allah SWT. Besides, leadership in the context of this study is an activity of guiding the path blessed by Allah SWT. Then, the leadership here is merely looking for or carrying out activities according to the path of Allah SWT.

According to Rifai and Arifin (2009), a leader must hold the Qur'an and the Hadith and have four qualities possessed by leaders: (1) Ash-Shidq (truth), meaning that a leader must be able to behave, say, and struggle to carry out his duties, (2) Al-Amanah (trust), meaning that a leader can make him maintain as well as possible what is presented to him both from God and from the people he leads, (3) Al-Fathanah (intelligence), which means that a leader must always be ready to face and overcome problems that arise as quickly as possible, and (4) At-Tabligh (honest), which means that a leader must be open to anyone and responsible.

The essential leadership roles in Islam are: 1) leaders must be flexible and have extensive experience; 2) considering "ceremonial" or "spiritual" responsibility as an organization/ company episode becomes a necessary function, not a trivial thing that must be experienced or delegated to others; 3 ) the created is not made effectively centralized at the top of the 
organization (Riva'i, 1974). Based on the leadership roles in the Islamic view above, it can be concluded that the vital role of leadership, according to the Islamic view, is the role of the leader who will bring an organization to the Islamic system that should be applied.

\subsection{Islamic Work Culture}

Work culture is stable from time to time, but never static (Robbins, 1998). A work culture consists of individual autonomy, structure, support, identity, performance appreciation, conflict tolerance, and risk tolerance. Therefore, the Islamic work culture must motivate, dynamism, and foster a dynamic nature to lead. Workers will realize the potential and power that God has given to them, such as creativity, reason, original thinking, special talents, the ability to use specific tools, and so on. It is called work culture from an Islamic perspective (Ahlami, 2003).

The Muslims' work culture faces the current globalization era. Many companies adopt foreign cultures because they are believed to be advanced and developed. Foreign culture is not always negative or positive, noted by Islam. The culture of respect for time and accuracy in fulfilling promises is always considered a foreign culture even though it is part of Islam's teachings (Hafinuddin \& Tanjung, 2003).

Islamic work culture means actualizing all the potential of faith, thought, remembrance, and knowledge to provide happiness. The cores or sources of inspiration for Islamic culture are the Qur'an and the Sunnah of Rasulullah SAW, which is bound together in one word, namely, morals. In Islam, humans are required to ask God for help and acknowledge their limitations. God loves those who always ask rather than those who are reluctant to ask because it seems as if humans were affluent. It is by the word of God (Surah Al-Mu'min: 60) means: "Pray to Me, I will surely allow it for you. Indeed, those who boast of worshiping me will enter Jahannam hell in humiliated condition "(Indonesian Ministry of Religion, 1989: 767).

If humans diligently work and strive, they will create a disciplined work culture that is hard-willed and not easily discouraged. Meanwhile, the individual continues to pray and ask for His help and blessing so that his efforts will be successful. This trait will bring people into humble behavior, fear, not arrogance, and always be aware of their weaknesses and strengths.

Hafinuddin and Tanjung (2003) affirmed that the appreciation of life's values or meanings, religion, experience, and education must be directed to create professional work attitudes. Meanwhile, the appreciation of applicable values will produce moral values, including Ash-Sholeh (Good and useful), Al-Itqon (Stability), Al-Ihsan (Doing the Best or Better), Al-Mujahadah (Hard and Optimal Work), Tanafus and Taawun (Competing and Helping), and Traits (Shiddiq, Istiqomah, Fathanah, Amanah, and Tabligh).

\subsection{Work Motivation}

Each person's or employee's motivation varies depending on the background. However, basically, motivation will affect employees' work performance and productivity. In his book entitled Working with Conscience, Akh. Muwafik Saleh (2009) stated that, so far, many people have worked to pursue mere material goals for the sake of worldly interests, and they do not care about the afterlife interests. Therefore, it is time for workers to work with a motivation that can provide a good personality and is justified by Islam by meeting the following characteristics: good and right intention (Hoping Allah's pleasure), devotion in work, and sincerity at work.

Motivation from an Islamic perspective, Abdul Hamid Mursi (1997), in his book Productive Human Resources in the Qur'an and Science Approach, has the following main concepts: physiological motivation, psychological or social motivation, and motivation to work and produce.

One of the essential differences regarding the motivation theory or needs among the theories put forward by the Western and Islam authors is the faith factor that underlies all human activities and motivates them to work. The needs' theories put forward by Western writers have been criticized by Eastern religious teachings. One fatal flaw in these theories is that they only see humans as mere material beings. For example, one of the manifestations in applying the time system is money, whereas humans are beings with double dimensions who have material elements and are also spiritual beings. In other words, humans are composed of physical and spiritual beings.

\subsection{Job Satisfaction}

An employee will feel comfortable and has high loyalty to an organization when he gets job satisfaction from what is desired. The first research on job satisfaction appeared in the 30th year of the 20th century (following the findings of E. Maya). According to Dole and Schroeder (2001), job satisfaction can be defined as an individual's feelings and reactions to his work environment. Meanwhile, Testa (1999), Dunnette et al. (1976), Robbins (1996), Luthans (1998), Schultz \& Schultz (1998), and Islam et al. (2016) defined job satisfaction as excitement or positive emotional statements resulting from the one job's assessment or work experiences and the difference of the work compensation received with the amount of worker compensation that should be received. The joy felt by employees will provide a positive influence and attitude for employees. An increase in job satisfaction for employees certainly has an impact on the performance 
they show. When employees felt satisfied with their work, a more significant impact would also affect the organization in general (Rain et al., 1991; Nguyen, 2019; Nguyen et al., 2020).

The other dimension of job satisfaction was also conveyed by Emilisa (2001), who cited the results of Desantis and Durts (1996), stating that the dimensions that can explain job satisfaction are:

1. Monetary and non-monetary rewards. Financial rewards, promotion opportunities, and fringe benefits were the variables that significantly related to job satisfaction based on the services provided.

2. Job characteristics. The employees who carried out their duties professionally employing skill variety, job significances, autonomy, and feedback would use their experience to achieve job satisfaction.

3. Work-environment characteristics. The work environment could increase job satisfaction, including office surroundings and atmosphere.

4. Personal characteristics. Some attributes of a person's character, such as sex, age, race, and education, were related to job satisfaction.

\subsection{Employee Performance}

Performance can be interpreted as the work result that can be achieved by a person or group of people in an organization in accordance with their respective authorities and responsibilities to achieve the organization objectives concerned legally, not violating the law, and in accordance with morals and ethics (Suryadi, 1999).

Performance measurement needs to be conducted to determine whether there is a deviation from the predetermined plan during the performance implementation or whether the performance results have been achieved as expected. Performance measurement can be carry out by:

1. Ensuring that the requirements desired by customers have been met

2. Striving for performance standards to create comparisons

3. Consideration of resource use

4. Establishing the importance of quality problems and determining priorities

5. Work planning

Kreitner and Kinicki (2003) said that measuring performance needs to meet the requirements, including:

1. In the position of observing performance behavior that is of individual interest

2. The ability to understand the dimensions or performance description

3. Having an understanding of the scale format and instruments

4. Having the motivation to work consciously
According to Bernardin and Russel, several employee assessment criteria have benefits in measuring employee performance (Kokasih, 2007):

1. Quality: The level at which a process of adjustment is an ideal way of carrying out activities or fulfilling activities as expected.

2. Quantity: The quantity of product produced is realized through the currency value or the amount of the activity cycle that has been completed.

3. Timelines: The level at which an activity has been completed with a predetermined time and maximizes the time for other activities.

4. Cost-Effectiveness: The extent to which the use of company resources in the form of human, finance, and technology is maximized to get high results.

5. Interpersonal impact: The degree to which an employee feels confident, has good intentions, and cooperates with colleagues.

\section{Hypothesis Development}

\subsection{Relationship between Islamic Leadership and Motivation}

GR Terry (Sutarto, 1995), in his book Principle of Management, asserted that leadership is an activity that influences people to try achieving group goals. Robnagel (2016) stated that leaders show the way and help employees pursue goals by empowering and engaging the employees (Gill, 2012) through "the ability ... influencing, motivating and enabling others to contribute to the organization's effectiveness and success". The studies that strengthen this concept are those of Naile and Selesho (2014), Rawung (2013), and Rahbi et al. (2017), which found that the leadership variable significantly influenced the work motivation variable. Thus, the following hypothesis is proposed:

H1: Islamic leadership has a positive effect on work motivation.

\subsection{Relationship between Islamic Leadership and Job Satisfaction}

Leadership in Islam is defined as leaders who carry out human functions as Khalifah on earth and must be based on Qur'an and Hadith. Islamic leadership will create subordinates' job satisfaction, which is significantly related to employee performance. Spiritual leadership plays an effective role in encouraging, motivating, and moving employees to behave to achieve their vision, mission, and goals. Spiritual leadership also encourages strong emotional ties within employees to accept the organization's goals 
and values, do their best for the organization's interests, and have high loyalty. Besides, spiritual leadership can also form positive work attitudes towards work. These conditions encourage a sense of comfort and pleasure (job satisfaction) to impact productive work behavior (Rahmawati, 2016; Paais and Pattiruhu, 2020; Pancasila et al. 2020). Thus, the following hypothesis is proposed:

H2: Islamic leadership has a positive effect on job satisfaction.

\subsection{Relationship between Islamic Work Culture and Motivation}

Work culture can help employees work because it creates an extraordinary level of motivation for employees to provide their best ability to take advantage of the opportunities provided by their organizations. Shared values make employees feel comfortable working, have commitment and loyalty, try harder, improve work and employee's job satisfaction, and maintain a competitive advantage. This relationship is supported by the studies conducted by Engin and McKeown (2012), Hasan and Hynds (2014), and Mustajbasic and Huzakovic (2016), which revealed that work culture positively and significantly affected work motivation. Thus, the following hypothesis is proposed:

H3: Islamic work culture has a positive effect on work motivation.

\subsection{Relationship between Islamic Work Culture and Job Satisfaction}

Organizational culture is a system applied and, at the same time, implemented in an organization. It can have a positive or negative effect on an employee's job satisfaction in an organization. Culture is a guideline for organization employees is behaving, a guideline in interacting with colleagues, and a guideline for decision making. Job satisfaction is obtained when employee expectations can be met. Based on the mindset above, work culture positively affects the employee's job satisfaction (Rahmawati, 2016; Paais \& Pattiruhu, 2020). Thus, the following hypothesis is proposed:

H4: Islamic work culture has a positive effect on job satisfaction.

\subsection{Relationship between Islamic Work Motivation and Employee Performance}

The expectation theory from Victor Vroom (Robbins, 2006: 238) provides a statement on the presence of a relationship of motivation with performance, as follows: "an employee will be willing to make greater efforts when he believes that the effort will result in a good performance appraisal, and a good performance appraisal will result in a salary increase and promotion. All of those allow a person concerned to achieve his personal goals. Mohamud et al. (2017), Bao and Nizam (2015), Haryono et al., (2020), Pawirosumarto et al. (2017), Paais and Pattiruhu (2020), and Shahzadi et al. (2014) discovered that work motivation positively and significantly affected employee performance. Thus, the following hypothesis is proposed:

H5: Islamic work motivation has a positive effect on employee performance.

\subsection{Relationship between Job Satisfaction and Employee Performance}

A person with a high level of job satisfaction showed a positive attitude towards his job, while someone dissatisfied with his job revealed a negative attitude (Robbins, 2006). Satisfied employees tended to be more effective than less satisfied ones (Robbins, 2007). Improved job satisfaction would impact the performance shown by employees who tended to be driven to take on new challenges at work (Rain et al., 1991; Pratheepkanth, 2011; Ingsih \& Astuti, 2019; Djastuti et al., 2019; Maryati et al., 2020; Srimindarti et al., 2020; Wikaningrum et al., 2018). Thus, the following hypothesis is proposed:

H6: Job satisfaction has a positive effect on employee performance.

\subsection{Relationship between Islamic Leadership and Employee Performance}

Leadership is the ability to influence others. A leader's success depends on his ability to influence. In other words, leadership can be interpreted as a person's ability to influence others through direct and indirect communication to drive his people to understand and willingly follow the leader's wishes. An effective leader is someone with these abilities. According to Tandoh (2011), the study found that the style or behavior centered on the work shown by a leader or manager had a positive effect on employee performance. It indicated that managers specifically aimed to get results and only motivated employees to provide the best in increasing productivity. However, it was also observed that very few or minimal employee-centered leadership styles were exhibited, and it negatively influenced performance. It might indicate that management acted with strict internal rules to achieve results, and in fact, this practice also did not strengthen the democratic centered style. The studies supporting 
this relationship are those of Pradeep and Prabhu (2011), Abdulahi Ali et al. (2013), Thompson and Webber (2016), Pawirosumarto et al. (2017), and Paais and Pattiruhu (2020) who found that leadership had a significant positive effect on performance. Thus, the following hypothesis is proposed:

H7: Islamic leadership has a positive effect on employee performance.

\subsection{Relationship between Islamic Work Culture and Employee Performance}

To achieve optimal employee performance, an organization usually makes a strategic effort, so a change in work atmosphere is needed in the form of a change in paradigm or perspective, mindset, and how to act in carrying out the organization's operational activities. Thus, the cultural transformation program in an organization can run well. An organization that has carried out this will have the characteristics of very basic, strategic, and comprehensive change so that the goals set in the form of vision and mission can be implemented. It corroborates the studies conducted by Paschal and Nizam (2016), Wanjiku and Agusioma (2014), Narayana (2017), Paais and Pattiruhu (2020), and Pancasila et al. (2020). Thus, the following hypothesis is proposed:

H8: Islamic work culture has a positive effect on employee performance.

\section{Research Methods}

The population used as the research object was all civil servants educational personnel of Universitas Islam Negeri Walisongo Semarang (186 people). However, only 127 respondents were involved in this study as the sample. The Islamic leadership variable measurement used four items (Rifa'i and Arifin, 2009), giving a loading value of 0.7490.915 . The Islamic work culture measurement employed six items (Hafinuddin \& Tanjung, 2003), giving a loading value of 0.764-0.949. Besides, work motivation utilized three items (Akh. Muwafik Saleh, 2009), resulting in a loading value of 0.739-0.937. The measurement of job satisfaction used six items (Robbins, 1996), resulting in a loading value of 0.8390.925 . Finally, the employee performance measurement employed four adopted items (Mathis and Jackson, 2006), providing a loading value of $0.778-0.945$. The research instrument test for validity utilized factor analysis and Cronbach's Alpha was employed for reliability. The data analysis was performed using multiple regression analysis.

\section{Results and Discussion}

This study involved 127 respondents, consisting of 70 men and 57 women. Their educational qualifications consisted of a Master's Degree, for 27 people; a Bachelor's Degree, for a total of 30 people; high school, for a total of 35 people; junior high school, for a total of 25; and elementary school, for ten people. The description of the four variables used in this study is presented for the mean, standard deviation, and correlation presented in Table 1 . The data analysis results used multiple linear regression as presented in Table 2.

The study found that two out of eight hypotheses tested were rejected, so six hypotheses were accepted. The hypotheses rejected are that leadership had no effect on employee performance with a significance value of 0.083 (> 0.05 ), and work culture had no effect on employee's work motivation with a significance value of $0.123(>0.05)$. The three models in this study also showed a fairly good fit, so they were expected to get a good level of confidence in this study's results.

Leadership had a positive effect on employee's work motivation at UIN Walisongo Semarang. It indicated that better leadership would increase the educational personnel's work motivation at Universitas Islam Negeri Walisongo Semarang. Thus, it could be said that the leadership roles, including loving the truth and only fearing Allah SWT, maintaining the trust and trust of others, being good at getting along, having the spirits to advance and devotion, and being responsible for making decisions, much determined the educational personnel's motivation. It was a successful leader in influencing and motivating (attempted leadership) educational personnel to follow and take actions ordered with an awareness of the benefits incurred so that the Universitas Islam Negeri Walisongo Semarang's goals are achieved. This study reinforces previous studies conducted by Naile and Selesho (2014), Rawung (2013), and Rahbi et al. (2017).

Islamic leadership also positively affected the employees/ educational staff's job satisfaction at UIN Walisongo. Spiritual values in leadership could motivate and inspire employees to build the organization's vision and culture and create employee's job satisfaction in the organization, which in turn impacted their employees' performance. This study verifies the research of Rahmawati (2016), which revealed that spiritual leadership had a positive effect on employee's job satisfaction.

Moreover, work culture had a positive effect on the employees' work motivation at UIN Walisongo Semarang. It showed that the roles of work culture, including ash-sholeh (good and beneficial), al-itqan (stability), al-ihsan (doing the best and better), al-mujahadah (hard work and optimal), tanafus (competing), and ta'awun (mutual help), could increase the educational personnel's motivation at Universitas Islam Negeri Walisongo Semarang. It indicated that the high level of competition in working and helping is a determinant of the employees' work motivation at Universitas Islam Negeri Walisongo Semarang. This study supports previous studies conducted by Engin and McKeown (2012), Hasan and Hynds (2014), and Mustajbasic and Huzakoviz (2016). 
Sih Darmi ASTUTI, Ali SHODIKIN, Maaz UD-DIN /

Journal of Asian Finance, Economics and Business Vol 7 No 11 (2020) 1059-1068

Table 1: Means, Standard Deviation, Correlation, and Reliability

\begin{tabular}{|c|c|c|c|c|c|c|c|c|}
\hline No & Variable & Means & SD & 1 & 2 & 3 & 4 & 5 \\
\hline 1 & Islamic Leadership & 5.321 & 0.671 & 0.897 & & & & \\
\hline 2 & Islamic Work Culture & 5.453 & 0.873 & 0.124 & 0.957 & & & \\
\hline 3 & Motivation & 4.543 & 0.756 & 0.425 & 0.102 & 0.852 & & \\
\hline 4 & Job Satisfaction & 4.654 & 0.865 & 0.422 & 0.324 & 0.254 & 0.832 & \\
\hline 5 & Employee Performance & 5.675 & 0.857 & 0.221 & 0.467 & 0.198 & 0.354 & 0.898 \\
\hline
\end{tabular}

Note: The value of alpha Cronbach is on the main of diagonal.

Table 2: Multiple Linear Regression Analysis

\begin{tabular}{|c|c|c|c|c|c|}
\hline $\begin{array}{l}\text { Dependent } \\
\text { Variable }\end{array}$ & Independent Variable & Standardized Path Coefficients & Probability & F test & Adjusted $\left(\mathbf{R}^{2}\right)$ \\
\hline \multirow[t]{2}{*}{ Motivation } & Islamic Leadership & 0.345 & 0.043 & 31.723 & 0.564 \\
\hline & Islamic Work Culture & 0.827 & 0.000 & & \\
\hline \multirow[t]{2}{*}{ Job Satisfaction } & Islamic Leadership & 0.776 & 0.000 & 29.987 & 0.475 \\
\hline & Islamic Work Culture & 0.692 & 0.000 & & \\
\hline \multirow{4}{*}{$\begin{array}{l}\text { Employee } \\
\text { Performance }\end{array}$} & Islamic Leadership & 0.161 & 0.093 & 35.160 & 0.609 \\
\hline & Islamic Work Culture & 0.158 & 0.104 & & \\
\hline & Motivation & 0.767 & 0.000 & & \\
\hline & Job Satisfaction & 0.675 & 0.002 & & \\
\hline
\end{tabular}

Islamic work culture was found to positively affect employee job satisfaction among the educational personnel of Universitas Islam Negeri Walisongo Semarang. An organization's success depends on its success in creating a distinctive organizational culture as part of a strategic plan. Therefore, organizational culture management was directed at the ability of culture to encourage increased organizational/ company performance through employee's job satisfaction. This study is in accordance with Rahmawati's (2016) research, which uncovered that work culture positively influenced employee's job satisfaction.

Besides, the test results proposed in this study discovered a positive effect of work motivation on performance. It showed that the educational personnel's motivational conditions could influence their performance. Thus, it could be said that the educational personnel who had been allowed to develop themselves through learning tasks, attending education leadership training, and other technical training as a provision to motivate them were proven to improve their performance. These results also align with previous studies by Mohamud et al. (2017), Bao and Nizam (2015), and Shahzadi et al. (2014).

This study also revealed a positive impact of UIN Walisongo employees' job satisfaction on their performance. Job satisfaction is closely related to employees' attitudes towards their work. The level of job satisfaction would be reflected in a positive work attitude. Therefore, job satisfaction must be created as well as possible so that work morale, dedication, love, discipline, and employee performance will improve. This study is consistent with the research of Rahmawati (2016) that job satisfaction had a positive effect on employee performance.

Furthermore, the test result proposed in this study was that there was no effect of Islamic leadership on educational personnel performance. It demonstrated that the leadership roles, including loving the truth and only fearing Allah SWT, maintaining the trust and trust of others, being good at getting along, having the spirit to move forward and serving spirit, and being responsible for making decisions, could not impact educational personnel's success and effectiveness in achieving the tasks at Universitas Islam Negeri Walisongo Semarang. This finding also implied that, whomever the leaders were, it was not a problem for the educational personnel, considering that they were senior employees who had already known their respective duties and responsibilities. This result does not support previous studies by Pradeep and Prabhu (2011), Abdulahi Ali et al. (2013), and Thompson and Webber (2016).

The test result proposed in this study was that there was no effect of Islamic work culture on performance. This condition 
signified that the educational personnel performance would not directly increase from the Islamic culture built at UIN Walisongo so far. It disclosed that, although the Islamic work culture developed by Universitas Islam Negeri Walisongo Semarang was strong enough for the educational personnel in the form of the employees with high work ethics, coming to work on time, having a firm working cohesion, it has not been able to strengthen performance directly. However, their performance, as indicated by the presence of tasks and responsibilities carried out by the educational personnel, was completed by the target to improve the work quality created through motivation and job satisfaction. These results are not consistent with previous studies by Paschal and Nizam (2016), Wanjiku and Agusioma (2014), and Narayana (2017).

\section{Conclusion}

Based on the analysis's results, the following conclusions could be drawn:

The educational personnel performance at Universitas Islam Negeri Walisongo Semarang was most strongly influenced by the Islamic work culture, and it was reflected in the work culture that always paid attention to time, al-mujahadah (hard work and always optimal), al-ihsan (doing the best or better), and had the nature of al-itqon (self-stability). The four principles had a powerful influence on improving the educational personnel performance at Universitas Islam Negeri Walisongo Semarang.

Islamic work culture was found not to have a direct effect on educational personnel performance. Islamic work culture would improve employee performance through their work motivation. It indicated that the Islamic work culture plays a vital role in improving employee performance. This work culture was proven to bind all members and employees because it would encourage uniformity among the organization members and increase the educational personnel's commitment, group efficiency, and overall performance.

Islamic leadership was revealed not to affect educational personnel performance directly, but through their job satisfaction. It denoted that the leaders play a role in increasing employee job satisfaction, ultimately impacting educational personnel performance.

Managerial policy implications that can be conveyed are as follows:

It is necessary to have a commitment and seriousness of the leaders and educational staff to maintain a robust Islamic work culture and carry out tasks to achieve an optimal performance of the educational personnel, for example, by giving more roles, participation, and confidence to the educational personnel.
In terms of leadership, the educational personnel needs direction and initiative from superiors to always improve their performance, and the subordinates also wish to contribute their thoughts and energy by providing advice and criticism to the leaders to develop the organization in the future. The involvement of the educational personnel and their participation are needed.

The research model found is relatively poor, so future research is expected to enrich it to examine more appropriate factors, mainly focusing on the objects in religious-based organizations, such as spirituality, individual, and work characteristics.

\section{References}

Abdulahi Ali, S. A., Elmi, H. O., \& Mohamed, A. I. (2013). The effect of leadership behaviors on staff performance in Somalia. Educational Research International, 2(2), 197-210.

Ahlami. (2003). Work Culture According to Islamic Perspective. Retrieved August 26, 2009, from http://haslizaali.blogspot. com/2009/12/budaya-kerja-menurut-perspektif-Islam.html. [Indonesian]

Al-Qur'anul Karim. Al Qur'an and Its Translation. Bandung, Indonesia: Diponegoro. [Indonesian]

Bao, C., \& Nizam, I. (2015). The Impact Of Motivation On Employee Performance In The Electronics Industry In China. International Journal of Accounting \& Business Management, 3(2), 29-45. Doi: 10.24924/ijabm/2015.11/v3.iss2/29.45.

Djastuti, I., Rahardjo, S. T., Irviana, L., \& Udin, U. (2019). Fun at work and employee performance: the roles of job satisfaction and organizational commitment in manufacturing companies. WSEAS Transactions on Business and Economics, 16, 153-162.

Engin, M., \& McKeown, K. (2012). Cultural influences on motivational issues in students and their goals for studying at university. Learning and Teaching in Higher Education: Gulf Perspectives, 9(1), 1-15.

Gill, R. (2012). Theory and practice of leadership. London, UK: Sage Publications.

Hafinuddin, D., \& Tanjung, H. (2003). Syari'ah Management in Practice. Jakarta, Indonesia: Gema Insani Press. [Indonesian]

Hasan, A. R., \& Hynds, A. (2014). Cultural Influence on Teacher Motivation-A Country Study of Maldives. International Journal of Social Science and Humanity, 4(1), 19-28. Doi: 10.7763/IJSSH.2014.V4.312

Haryono, S., Supardi, S., \& Udin, U. (2020). The effect of training and job promotion on work motivation and its implications on job performance: Evidence from Indonesia. Management Science Letters, 10(9), 2107-2112.

Ingsih, K., \& Astuti, S. D. (2019). Determinant Factors of Police Performance. International Journal of Innovation, Creativity and Change, 9(2), 250-261. 
Islam, Z., Bangish, S. B., Muhammad, H., \& Jehan, A. S. (2016). The impact of HR practices on job satisfaction: A case study of hotel industry in Pakistan. Journal of Asian Finance, Economics and Business, 3(1), 43-48. Doi: 10.13106/jafeb.2016.vol3.no1.43

Maryati, T., Astuti, R. J., \& Udin, U. (2020). The effect of spiritual leadership and organizational culture on employee performance: The mediating role of job satisfaction. International Journal of Innovation, Creativity and Change, 9(3), 130-143.

Ministry of Religion of the Republic of Indonesia. (2010). Guidelines for the Formulation of Standard Operating Procedures within the Ministry of Religion of the Republic of Indonesia, Number 168 of 2010. [Indonesian]

Ministry of Religion of the Republic of Indonesia. (2016). Organization and Administration of the Ministry of Religion of the Republic of Indonesia, Number 24 of 2016. [Indonesian]

Ministry of Religion of the Republic of Indonesia. (2016). Organization and Work Procedure of UIN Walisongo Semarang Number 54 of 2016. [Indonesian]

Kosasih, N., \& Budiani, S. (2008). The influence of knowledge management on employee performance: A case study of the Surabaya Plaza Hotel front office department. Jurnal Manajemen Perhotelan, 3(2), 80-88. [Indonesian]

Kinicki, A., \& Kreitner, R. (2006). Organizational behavior: Key concepts, skills \& best practices. New York, NY: McGraw-Hill/ Irwin.

Mohamad, S., Abdullah, A. N., \& Adnan, M. A. (2012). Islamic leadership secrets and the glory of the country according to the script of the Al-Quran. The 2nd Annual International Qur'anic Conference. Kuala Lumpur: Centre of Quranic Research Universiti of Malaya.

Mohamud, S. A., Ibrahim, A. A., \& Hussein, J. M. (2017). The Effect Of Motivation On Employee Performance: Case Study In Hormuud Company In Mogadishu Somalia. International Journal of Development Research, 7(11), 17009-17016.

Mustajbasic, E., \& Huzakovic, D. (2016). Impact of Culture on Work Motivation: Case of Bosnia and Herzegovina. Journal of Business and Economic Policy, 3(3).

Naile, I., \& Selesho, J. M. (2014). The role of leadership in employee motivation. Mediterranean Journal of Social Sciences, 5(3), 175-182. Doi: 10.5901/mjss.2014.v5n3p175

Narayana, A. (2017). A Critical Review of Organizational Culture on Employee Performance. American Journal of Engineering and Technology Management, 2(5), 72-76. Doi: 10.11648/j. ajetm.20170205.13.

Nguyen, H. H. (2019). The Study on People's Satisfaction towards Public Services of Vietnam: Evidence of Tra Vinh Provincial Center of Public Administrative Services. Journal of Asian Finance, Economics and Business, 6(2), 183-187. Doi: 10.13106/jafeb.2019.vol6.no2.183
Nguyen, H., Nguyen, L. T. B., Nguyen, H. N., Le, T. H., \& Do, D. T. (2020). Critical Factors Affecting Employers' Satisfaction with Accounting Graduates in Hanoi. Journal of Asian Finance, Economics and Business, 7(8), 613-623. https://doi. org/10.13106/jafeb.2020.vol7.no8.613

Paais, M., \& Pattiruhu, J.R. (2020). Effect of Motivation, Leadership, and Organizational Culture on Satisfaction and Employee Performance. Journal of Asian Finance, Economics and Business, 7(8), 577-588. https://doi.org/10.13106/ jafeb.2020.vol7.no8.577

Pancasila, I., Haryono, S., \& Sulistyo, B. A. (2020). Effects of Work Motivation and Leadership toward Work Satisfaction and Employee Performance: Evidence from Indonesia. Journal of Asian Finance, Economics and Business, 7(6), 387-397. https:// doi.org/10.13106/jafeb.2020.vol7.no6.387

Paschal, A. O., \& Nizam, I. (2016). Effects of organisational culture on employees performance: case of Singapore telecommunication. International Journal of Accounting \& Business Management, 4(1), 19-26. Doi: 10.24924/ ijabm/2016.04/v4.iss 1/19.26.

Pawirosumarto, S., Sarjana, P. K., \& Muchtar, M. (2017). Factors Affecting Employee Performance of PT. Kiyokuni Indonesia. International Journal of Law and Management, 59(4), 602614. https://doi.org/10.1108/IJLMA-03-2016-0031

Pradeep, D. D., \& Prabhu, N. R. V. (2011). The relationship between effective leadership and employee performance. Journal of Advancements in Information Technology, 20(1), 198-207.

Rahbi, D. A. (2017). The Effects Of Leadership Styles On Team Motivation. Academy of Strategic Management Journal, 16(2), $1-14$.

Rawung, F. H. (2013). The effect of leadership on the work motivation of higher education administration employees (Study at Manado State University). IOSR Journal of Business and Management, 15(1), 28-33.

Rivai, V. (1974). Tips for Leading in the 21st Century. Jakarta, Indonesia: Murai Kencana. [Indonesian]

Robbins, S. P., \& Judge, T. (2003). Essentials of organizational behavior (Vol. 7). Upper Saddle River, NJ: Prentice Hall.

Robnagel, C. S. (2016). Leadership Today. Cham, Switzerland: Springer International Publishing.

Shahzadi, I., Javed, A., Pirzada, S. S., Nasreen, S., \& Khanam, F. (2014). Impact of employee motivation on employee performance. European Journal of Business and Management, 6(23), 159-166.

Srimindarti, C., Oktaviani, R. M., Hardiningsih, P., \& Udin, U. (2020). Determinants of job satisfaction and performance of auditors: A case study of Indonesia. Quality - Access to Success, 21(178), 84-89. 
Suryadi, P. (1999). Employee Performance Policy. Yogyakarta, Indonesia: BPFE. [Indonesian]

Thompson, K., \& Webber, J.K. (2016). Leadership Best Practices And Employee Performance: A Phenomenological Telecommunication Industry Study. Global Journal of Business Research, 10(1), 41-54.

Wanjiku, N. A., \& Agusioma, N. L. (2014). Effect of Organisation Culture on Employee Performance in Non-Governmental
Organizations. International Journal of Scientific and Research Publications, 4(11), 1-12.

Wikaningrum, T., Udin, U., \& Yuniawan, A. (2018). The relationships among leadership styles, communication skills, and employee satisfaction: A study on equal employment opportunity in leadership. Journal of Business and Retail Management Research, 13(1), 138-147. 